\title{
Converging party systems in Russia and Central Asia: A case of authoritarian norm diffusion?
}

\author{
Sean P. Roberts \\ University of Portsmouth \\ Milldam, Burnaby Road, Portsmouth, Hants PO1 3AS \\ Phone: 02392842798 \\ E-mail: sean.roberts@port.ac.uk
}

\begin{abstract}
Almost twenty five years after the collapse of the Soviet Union, Russia and several Central Asian republics appear to be converging on what may be termed a 'hierarchic party system', characterised by controlled and unequal competition between parties. Addressing the juncture between international politics and party politics, this article explores this convergence and considers Russian authoritarian norm diffusion as a possible explanation. This article argues that although Russia continues to build significant party-based linkage in Central Asia, similarities between party systems are the result of complex, multi-directional norm diffusion, as regimes look to liberalise or close their respective political systems.

Keywords: party system; Russia; Central Asia; norm diffusion; authoritarianism; party of power
\end{abstract}




\section{Introduction}

The aim of this article is to provide much needed detail on Russian and Central Asian party systems, but also to engage with the related issue of authoritarian norm diffusion. Despite the fact that the five former Soviet Central Asian republics embarked on their own independent political course in 1991, there is a growing consensus that Russia, as the key regional actor, 'sets' the political agenda and is increasingly exporting and supporting authoritarian values (Ambrosio, 2008; Bader et al., 2010; Burnell, 2010; Cameron and Orenstein, 2012; Hyde, 2011; Kästner 2010; Kramer 2008; Tolstrup 2009). Moreover, the two seemingly unrelated issues of party politics and norm diffusion have caught the attention of academics working in the region, in particular the 'striking' similarities between the Russian party of power, 'United Russia' and the Kazakhstani equivalent, 'Nur Otan' (Del Sordi, 2011). Indeed, by 2015, there are growing similarities between the Russian party system and its counterparts in Kazakhstan, Tajikistan and Uzbekistan, with signs that Kyrgyzstan and Turkmenistan may follow suit. This type of party-system may be termed 'hierarchic' in the sense that party competition is controlled and unequal, with a clear stratification between parties, based on their relationship with the authoritarian regime in question. At the top of the hierarchy are so-called 'parties of power' or regime parties that, although unequivocal leaders in these party-systems, are none the less subservient to the president and executive branch (Bader, 2011; Roberts, 2012a). At the next level of importance is a coterie of systemic or 'soft' opposition parties, affording the party system an outward appearance of pluralism, but without ever challenging the regime. The lowest rung of the party system sees a mixture of minor soft opposition parties, but also anti-systemic or 'hard' opposition groups, which are typically marginalised by the regime, denied official registration, and/or their leaders imprisoned or exiled from the country completely. 
In line with the growing interest in authoritarian norm diffusion in the post-Soviet space, could it be that Russia, having successfully engineered its own hierarchic party system, is now exporting its know-how to Central Asia in a bid to thwart the spread of democracy and bolster pro-Moscow regimes? To answer this question this article proceeds as follows. The first part briefly outlines the emerging literature identifying Russia's support of authoritarianism in the post-Soviet space. This material also characterises the hierarchic party system that was established early on in Vladimir Putin's first term of office (2000-4). The second part then examines the similarities between party systems in Russia, Kazakhstan, Tajikistan and Uzbekistan, as well as the growing authoritarian linkage between United Russia and analogous parties of power in these aforementioned states. The final part then considers some of the problems with Russian norm diffusion as an explanation for party system convergence, as well as the outlier cases of Kyrgyzstan and Turkmenistan.

Despite the undoubted influence of Russia in post-Soviet Central Asia and unequivocal evidence that United Russia is building substantial linkage with other parties in the region, this article argues that Russian norm diffusion is only a partial explanation for convergence. Instead, party system convergence appears to be the result of complex, multidirectional norm diffusion, as regimes look to liberalise or close their respective political systems by 'emulating' or 'rejecting' political innovations seen in neighbouring regimes.

This article draws on a range of primary and secondary sources, as well as a close comparative analysis of the three levels of the hierarchic party-system already identified, including individual parties of power, and soft and hard opposition in Russia and the five former Soviet Central Asian Republics of Kazakhstan, Kyrgyzstan, Uzbekistan, Tajikistan and Turkmenistan. Where possible, official documents, such as party statues and manifestoes are examined, as too party laws and constitutional provisions governing the political systems in the respective states. This article also draws on data gathered from over 80 face-to-face 
interviews conducted by the author in Moscow in 2007 and in 2014 with members of the political establishment, including United Russia, as well as interviews conducted with the main opposition parties in Bishkek in 2012 during a sixth month research visit. ${ }^{1}$

\section{Russian norm diffusion \& the hierarchic party system}

The concept of 'norm diffusion', also termed 'norm transmission' (Mills and Joyce 2006) is by no means new, but its application in recent years has coincided with a refocused research agenda in response to the perceived shortcomings of 'third wave' democratisation in the post-Soviet space. The idea of 'negative' norm diffusion is intuitively appealing in the sense that Western actors, notably the US and the EU, have been engaged in 'good' democratic norm diffusion for some time (Finnemore and Sikkink, 1998; Pevehouse, 2002). The current interest in authoritarian norm diffusion simply inverts the focus while employing the same 'passive' and 'active' mechanisms found in the literature on the democratic equivalent (see Levitsky and Way, 2012, 38-9; Manners, 2002, 244-5).

Indeed, it is the nature of the international system, of weak and strong states, that provides the opportunity for norm diffusion to occur in the first place, with certain states possessing greater potential to prioritise, spread and establish their norms. According to Levitsky and Way (2005), states which have the greatest potential to diffuse norms are those which have the greatest linkage and leverage. Leverage, relates to conditionality, sanctions, diplomatic pressure and military intervention $(2005,21)$ and its success reflects the size and strength of the actor applying the pressure, relative to the actor resisting. Linkage on the other hand is more subtle and has a number of aspects, including economic, geographical, social, communication and transnational civil society. Importantly, linkage also includes party

\footnotetext{
${ }^{1}$ I would like to thank the OSCE Academy in Bishkek, Kyrgyzstan, for their assistance in conducting this research in 2012. I would also like to thank the Finnish Institute of International Affairs for providing me an opportunity to conduct follow up fieldwork in Moscow in 2014.
} 
organisations, which may help increase the exposure and susceptibility of states to foreign norms $(2005,23)$.

In terms of linkage and leverage, it is obvious that Russia, as an undoubted regional hegemon, has a great deal of influence over its post-Soviet neighbours; a point that the literature is increasingly highlighting. Building on the work of Levitsky and Way, Cameron and Orenstein (2012), identify Russia's favourable 'asymmetry of power', understood in terms of social or ethnic linkage (the large number of ethnic Russians living in its 'near abroad'); economic linkage (the importance of the Russian market for other post-Soviet republics); and growing international linkage (mainly through newly created institutions). The last point relates to the Eurasian Economic Union, the Shanghai Cooperation Organisation and the Collective Security Treaty Organisation; all of which have received impetus in recent years. In fact, the idea of regional hegemons diffusing authoritarian norms through transnational and international actors has begun to receive scholarly attention, in particular the Russian-Sino dominated Shanghai Cooperation Organisation and its clearly stated reverence for state sovereignty and non-interference in internal affairs - interpreted as norms that delegitimize anti-regime activities and democracy promotion (Ambrosio, 2008, 1341). However, the idea of a regional hegemon exporting a domestic political model has so far received less analysis. None the less, the similarities between party-systems in Russia and several Central Asian republics raise some interesting questions. Del Sordi $(2011,12)$, for example, asks if Russia is actively 'promoting' and 'encouraging' the formation of parties of power elsewhere, noting that several post-Soviet countries, including the Central Asian republics, have shown great interest in implementing the autocratic tools used to maintain 'authoritarian stability' in Russia.

While the 'authoritarian tools' at the disposal of the Putin regime are numerous, one of the key innovations in Russia in the post-Yeltsin period (2000-2012) has been to create a 
façade of relatively convincing political competition based around a party system and parliament controlled by a dominant, yet subservient ruling party with soft opposition providing the necessary pluralistic element and hard opposition marginalised or outlawed completely. Overall, this kind of party-system engineering is important for regime longevity, as elections in Russia, as in similar 'half-way houses', continue to be the main drivers of 'stability and change' in the political system (Schedler, 2006, 12).

In terms of the Russian case, to date, United Russia is the paramount party within the hierarchic party system, 2001-15. The party emerged through a process of reconciliation following the December 1999 State Duma election, when the Kremlin-backed 'Unity' party clashed with the party of the regions, 'Fatherland All-Russia', the two parties finally merging in December 2001 following Vladimir Putin's presidential election victory in March of the previous year. From December 2001, United Russia quickly developed a large, all-national organisation, establishing itself as the dominant electoral force in federal and regional elections and enjoying a State Duma majority from 2003 onwards.

The appearance of United Russia was both enabled and augmented by a broader process of political consolidation, in particular the consolidation of presidential power (20004), synonymous with the creation of the so-called 'power vertical' (Roberts, 2012b, 162). This consolidation enabled the creation and development of United Russia, but also the establishment of the important legal framework needed to control the party system, promote the party of power and limit opposition parties.

In terms of party system control, the main (but by no means only) approach taken by the post-Yeltsin regime has been to establish control over the supply of parties, in particular through the 2001 law 'On Political Parties' - a key moment in reorganising party politics in the country. In essence, this law adds to the legitimacy of the electoral process by creating legal 'pressure points' over existing parties while raising barriers to the formation of new 
parties, thus avoiding an over-reliance on less subtle, 'downstream' measures associated with election commission intervention, dubious interpretations of electoral law and, of course, electoral fraud - although they none the less persist.

The important point is that while party law is not the only means to regulate the Russian party system, it is the cornerstone of control, as it allows the authorities to simultaneously promote its party of power and to 'incentivise' loyal or soft opposition and to exclude hard opposition (Bacon, 2004; Karvonen, 2007; Moraski, 2006; Smyth et al., 2007). Karvonen (2007) concludes that non-democratic states use party law for a variety of reasons, including obstructing certain kinds of parties while granting other parties a privileged position. Moraksi underlines this point, acknowledging that the 2001 law 'On Parties' was primarily designed to establish a lasting party of power able to weaken the independent policies of regional power-holders and to boost the authority of the president and federal centre (Moraski 2006, 215).

In a parallel, but equally important development, Russia's hierarchic party system was also accompanied by the development of key 'ideas' in domestic political discourse, notably the importance of elite and societal 'unity' and, more broadly, 'sovereignty', that served to underpin and justify the controlled and unequal party system. The idea of elite and societal 'unity', it should be noted, was a key theme in Putin's election victory in 2000, against the backdrop of conflict in Chechnya, the perceived threat of state breakup and a general yearning for 'stability' among the electorate. In short, United Russia's entire raison d'être is tied up in the idea of 'unity' and the party's programmatic material provides consistent references to the complexity of the Russian state, including its multi-ethnic and multi-religious status that requires bounded political competition to maintain this delicate societal 'ecosystem'.

In terms of 'sovereignty', in 2006 United Russia incorporated so-called 'sovereign democracy’ into its official ideology. Although receiving varying interpretations, sovereign 
democracy emphasises traditional Russian values; the need for Russia to follow its own style of democracy, to maintain economic growth and to preserve Russia's borders (Tret'yakov, 2007). Among other things, sovereign democracy has been described as an attempt to simultaneously expand the political field for the regime and legitimise the party of power, while providing the ideological and operative grounds for narrowing the scope of public politics (Okara, 2007, 10-11).

\section{Central Asia: converging on the Russian model?}

Although there remain relatively few comparative studies on party politics in postSoviet Central Asia (Bader 2009, 2011; Ishiyama 2008), even a cursory glance at the cases of Tajikistan, Uzbekistan and, in particular, Kazakhstan, reveals a clear pattern of electorally dominant parties of power, nonetheless subservient to the president and the executive branch, accompanied by a host of soft opposition parties, with hard opposition groups typically unable to gain official registration or exiled completely. As shown in Table 1, by 2015, the party systems in Tajikistan, Uzbekistan, Kazakhstan, and Russia appear to have more than a passing resemblance. 
Table 1. Four-Country Comparison of Party Systems (2015)

\begin{tabular}{|c|c|c|c|c|}
\hline & Kazakhstan & Tajikistan & Uzbekistan & Russia \\
\hline Political system & Presidential & Semi-presidential & Presidential & Semi-presidential \\
\hline Main party of power & Nur Otan & $\operatorname{PDPT}(a)$ & $\operatorname{UzLiDep}(b)$ & United Russia \\
\hline Party of power leader & $\begin{array}{l}\text { Nursultan } \\
\text { Nazarbaev } \\
\text { (President of } \\
\text { Kazakhstan) }\end{array}$ & $\begin{array}{l}\text { Emomali } \\
\text { Rakhmon } \\
\text { (President of } \\
\text { Tajikistan) }\end{array}$ & $\begin{array}{c}\text { Mukhammadyusuf } \\
\text { Teshbaev } \\
\text { (parliamentarian) }\end{array}$ & $\begin{array}{l}\text { Dmitri Medvedev } \\
\text { (Prime Minister) }\end{array}$ \\
\hline Name of parliament & Mazhilis & Majlisi Oli & Oliy Majlis & $\begin{array}{c}\text { Gosudarstvennaya } \\
\text { Duma }\end{array}$ \\
\hline Electoral system & party list & $\begin{array}{c}\text { Mixed } \\
\text { list/majority }\end{array}$ & $\begin{array}{l}\text { Majority } \\
\text { (2 rounds) }\end{array}$ & $\begin{array}{c}\text { Mixed } \\
\text { list/majority }(c)\end{array}$ \\
\hline $\begin{array}{c}\text { Number of } \\
\text { parliamentary parties }\end{array}$ & 3 & 5 & $5(d)$ & 4 \\
\hline $\begin{array}{c}\text { Number of effective } \\
\text { parliamentary } \\
\text { parties }(e)\end{array}$ & 1.37 & 1.50 & 4.20 & 2.80 \\
\hline
\end{tabular}

Source: Inter-Parliamentary Union, http://www.ipu.org/english/home.htm (accessed May 09, 2015)

a. People's Democratic Party of Tajikistan.

b. Movement of Entrepreneurs and Business People-the Liberal Democratic Party of Uzbekistan.

c. Russia reverted back to the previous mixed electoral system in February 2014.

d. Including the allocation of 15 seats for the Ecological Movement of Uzbekistan (EMU).

e. Author's calculations using the Laakso and Taagepera formula (1979).

The differences between political systems, according to Table 1, include the modest distinction between semi and full presidential status, which relates primarily to the lack of constitutional power afforded to the post of prime minister in both Kazakhstan and Uzbekistan. Elsewhere, the fact that Russian and Uzbek presidents are not the leaders of their respective parties of power is a matter of preference. Russian president, Vladimir Putin, and Uzbek president, Islam Karimov, have, by and large, maintained an 'above party politics' status while none the less enjoying a close relationship with their parties of power. Vladimir 
Putin was leader of United Russia (2008-12) without becoming a member, and both Putin and Karimov have maintained close ties with other party and quasi-party structures. As of 2015, these structures include the all-Russian Popular Front (formed in 2011) and the Uzbek People's Democratic Party of Uzbekistan (the communist successor party formed in 1991), respectively.

In terms of dominance, each party of power has enjoyed consecutive election victories and each exists as the 'majority' party in its respective parliament. In December 2011, United Russia overcame a difficult election period to gain a working parliamentary majority with 238 of 450 seats. The Communist Party (92 seats), A Just Russia (64 seats) and the Liberal Democratic Party of Russia (56 seats) complete the complement of soft or, what has been termed, 'within system opposition' (Hutcheson, 2012, 2). Both the Progress Party and the Republican-PARNAS party are examples of hard opposition. The Republican-PARNAS party was de-registered by the Ministry of Justice in 2007 for failing to meet the minimum membership requirements of the aforementioned law 'On parties' (article 3), although the fact of its opposition to Putin was likely decisive in this outcome. However, a ruling from the European Court of Human Rights saw it re-registered by the authorities in 2012 (Novak, 2012).The Progress Party was subject to a court ruling in January 2015 that upheld a previous ban on registering the party for failing to meet similar minimum requirements (Novaya gazeta 2015). The Progress Party is led by high-profile opposition figure Aleksei Navalny, who has himself been the subject of several politically motivated criminal investigations since 2012 .

In Kazakhstan, the 2012 parliamentary election saw Nur Otan win 83 of 98 available seats, with Ak Zhol (8 seats) and the Communist People's Party of Kazakhstan (7 seats) comprising the soft opposition (see Peleschuk, 2012). The Alga Party is a notable representative of the hard opposition. Alga's leader, Vladimir Kozlov, was given a seven year jail sentence for inciting social hatred in October 2012 (Freedom House, 2012a) and a court 
ruling two months later ordered the party's closure (Lillis 2012). The Alga party, formed in 2006, traces its origins to the 'Democratic Choice of Kazakhstan' (formed in 2001) which, like Alga, was also denied registration by the Ministry of Justice.

In Tajikistan, the March 2015 elections to the Majlisi Oli saw the People's Democratic Party of Tajikistan (PDPT) win a convincing 51 of 63 seats with a host of opposition parties also gaining representation, including the Agrarian Party of Tajikistan (5 seats), the Party of Economic Reforms of Tajikistan (3), the Communist Party of Tajikistan (2) and the Socialist Party of Tajikistan (2). Although Tajikistan has experienced armed conflict along party lines in the 1990s, each of the opposition parties in the Majlisi Oli has close contacts with the regime and retains a questionable opposition status (Heathershaw, 2009, 1326-7). As of 2015, both the Islamic Revival Party (IRP) the Social Democratic Party of Tajikistan (SDPT) represent non-parliamentary hard opposition. The arrest of Islamic Renaissance Party leader, Sherik Karamkhudoev, in August 2012 was seen as the start of a campaign to eradicate all but the 'most loyal' opposition parties (see Freedom House, 2012b) and the run up to the most recent March 2015 parliamentary election saw the arrest of several IRP and SDPT candidates (OSCE, 2015(a), 3).

The two round parliamentary elections in Uzbekistan (Oliy Majlis) in December 2014/January 2015 saw UzLiDeP win 52 of the 135 contested seats, with the Democratic Party of Uzbekistan (36), the People's Democratic Party of Uzbekistan (27) and the Social Democratic Party of Uzbekistan (20) completing, what appears a relatively balanced parliament. In fact, the extent of Karimov's ties with all registered parties makes the relatively high number of 'effective parliamentary parties' (shown in Table 1) less significant. The measure of effective parties, as discussed in the next section, refers to the distribution of seats among parliamentary parties and can be taken as a proxy for single party dominance. As each 'opposition' party in the Oliy Majlis backed Karimov during the 2007 presidential election 
(OSCE, 2007) and as the presidential hopefuls forwarded by the same opposition parties portrayed Karimov as the 'best candidate' in the March 2015 presidential election campaign (OSCE, 2015(b), 8), the score of 4.20 parties does not reveal the true extent of regime dominance over the party system. Hard opposition parties include the 'Democratic Party ERK' and 'Birlik', whose leaders, as of 2015, are both in exile. Both parties were formed in the late 1980s, with ERK leader, Mohammed Salikh, actually running against current incumbent Karimov in the 1991 presidential election (Salikh 2013).

\section{The Russia-Kazakhstan juncture}

While the outward appearance of these party systems supports the idea of convergence, there is little to suggest Russian authoritarian norm diffusion as an explanation. However, a closer examination of the cases of Russia and Kazakhstan - the latter one of Russia's closest post-Soviet partners - is more persuasive. In particular, their respective parties of power (United Russia and Nur Otan) share a number of specific similarities that are difficult to ascribe to coincidence alone.

Both parties have developed features associated with classical mass parties (Duverger, 1964) including complex physical organisations and large memberships. As of March 2015, Nur Otan retains 5,598 offices located across 16 regional branches and a total membership of 850,000 (Radiotochka, 2015). As of January 2015, United Russia boasts 82,631 offices (UR, 2015) and a membership of 2,009,937 (MinJust 2015). Nur Otan's membership, when measured as a percentage of the voting age population is particularly high (6.6) compared to United Russia (1.7), but in view of the reliance of both parties on administrative resources and the insignificance of membership subscriptions for party financing (United Russia abolished mandatory member subscriptions in 2008) neither can be considered genuine mass parties. 
Instead, the attempt to create a mass party image reflects a shared electoral strategy, based around the idea of 'societal and elite unity' already mentioned. ${ }^{2}$

Other similarities between Russian and Kazakhstani parties of power are by no means difficult to find. For example, in August 2007, and in an attempt to demonstrate transparency and boost the party's image, United Russia introduced 'party primaries', allowing party members to determine the group of candidates for inclusion on regional party lists ahead of elections (Moiseev, 2007). Twelve months later, on July 30, 2008, Nur Otan assimilated this practice, conducting its first party primary in Kyzylordinskom Oblast' (Zakon.kz, 2008).

The development of party-based youth organisations is also highly suggestive of Russian influence over Kazakhstani development. For example, United Russia’s youth wing, Molodaya Gvardia, created in November 2005 to develop the party's cadre, has a general statutory aim of 'attracting young people into the process of building a democratic, socially just society' (MG, 2015a). Nur Otan's youth wing, Zhas Otan, was a little later in formally organising, holding its founding congress in July 2008. According to its statutes, Zhas Otan has an identical primary aim of 'attracting young people into the process of building a democratic, socially just society' (ZO, 2015).

Aside from sharing similar statutes, both party youth organisations oversee similar projects in their respective political systems, such as creating cadre reserves and youth parliaments, and both reflect the on-going regime 'battle' for young people's hearts and minds, but with Kazakhstan seemingly mirroring Russia’s moves. For example, in September 2007, Putin's presidential decree 1273 saw the creation of a state committee to coordinate youth politics in Russia (RG 2007). A year later, at Zhas Otan's founding congress in July 2008, key note speaker, President Nursulan Nazarbaev, announced the creation of an analogous Kazakhstani presidential council to coordinate youth politics (Nikitina, 2008).

\footnotetext{
${ }^{2}$ Calculated by the author and based on voting age population from the most recent 2012 Russian presidential election and the 2015 Kazakhstani presidential election (data available at: http://www.idea.int/index.cfm).
} 
Alongside party based similarities, the general development of the political systems in Russia and Kazakhstan is also highly suggestive of the influence of the former over the latter. For example, in April 2005, the Russian parliament approved the creation of the Public Chamber as a non-partisan oversight committee, but with strong connections with United Russia. This chamber held its first plenary session in 2006 with the stated aims of encouraging cooperation between citizens and the state. In September 2005, President Nazarbaev initiated the formation of the Kazakhstani Public Chamber (originally intended to be a chamber of public experts) which came into existence in 2007 to coordinate the activities of the state and civil society (Bapakova, 2008) - but essentially forming an extra layer of state control over civil society, as in Russia.

In terms of the influence of Russia on its neighbour, it is clear that Kazakhstan pays close attention to Russian developments. A former senior official who worked for the Nazabaev Administration on a range of domestic political issues, including party-building, underscores the importance of Russia:

'Russia was lucky [after the collapse of the Soviet Union] in the sense that the main intellectual resources stayed within the country, so we were able to learn from Russia. ... In the initial stages of economic development we copied the Russian experience, copied Russian legislation.' (Personal Communication, October 28, 2007).

\section{Different names, same parties of power?}

The Russian and Kazakhstani parties of power have many shared features, but there are deeper similarities between parties of power in each of the four cases in question. As shown in Table 2, the actual structure of parties of power in Kazakhstan, Tajikistan and Uzbekistan have a notable degree of overlap with United Russia and these organisational similarities are not arbitrary. For example, in each case, the party of power is built on the 'territorial principle', which means that each party is superimposed over existing 
administrative boundaries, helping to consolidate the integrity of the state by acting as an extra layer of regime control in each regional unit. The ability of the party leadership to liquidate branches (except Nur Otan) reinforces the regime's control over regional elites..

In terms of membership, the somewhat contradictory attitude of all parties toward exclusivity and inclusivity reveals the process of de-partification that accompanied the creation of presidential republics in 1991, in particular the requirement that party membership is suspended or terminated upon entering state service. Elsewhere, the restriction on membership of other parties is a rational measure to build elite cohesion, while the willingness of Russian, Tajik and Uzbek parties of power to accommodate non-members in their parliamentary factions allows them to absorb defectors from soft opposition parties. The distinction between 'supporter' and 'member' (United Russia and UzLidep) makes the party more attractive to high ranking elites who wish to work with the party, but who hold reservations about its longer-term viability and popularity. 
Table 2. Overview of Party Organisations

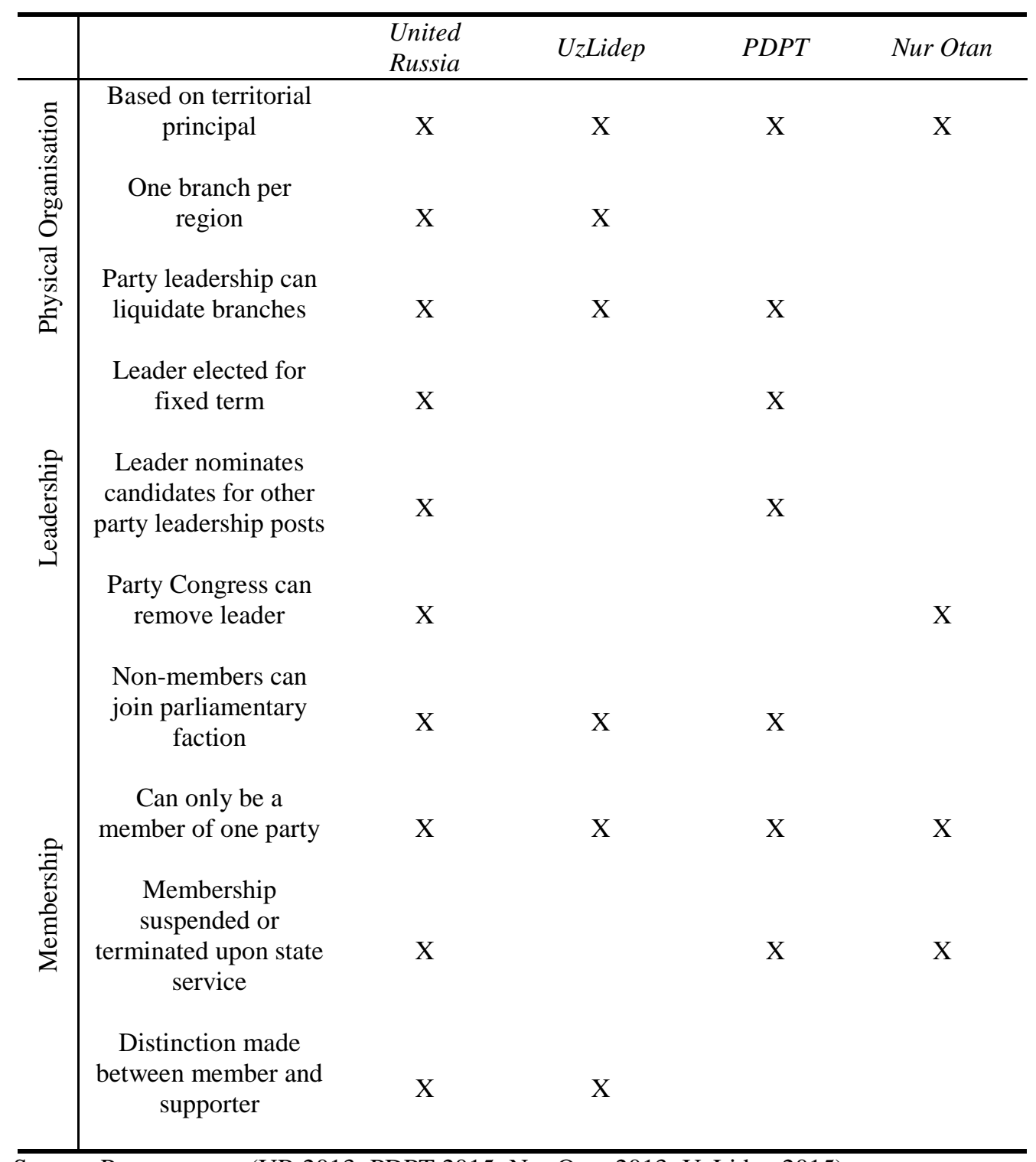

Source: Party statutes (UR 2013; PDPT 2015; Nur Otan 2013; UzLidep 2015).

In addition to organisational similarities, there are also common ideological strands, fully in line with United Russia's 'unity' and 'sovereignty' discourse. One does not have to try too hard to find these same themes repeated in Kazakhstani, Tajik and Uzbek party of power programmes, albeit with slightly differing emphasis. For example, Nur Otan's 2007 party programme openly discusses the importance of consolidating the country's complex society into a 'united Kazakhstan', highlighting the danger of 'mechanistically' following foreign recipes of 'forced democracy’ (Nur Otan, 2007, 9). UzLidep's 2009 and 2014 party 
programmes talk broadly of the need to increase stability in society, explicitly stating that the party's conception of external politics is based on respect of sovereignty and the noninterference in the internal matters of other states (UzLidep, 2014). Tajik president, Emomali Rakhmon, outlined the PDPT's programme at the party's Tenth Congress in 2009 in Dushanbe to include: the important role of the party in strengthening state sovereignty. According to Rakhmon, both the main achievement and task of the party is the establishment of 'stability' and 'national unity' (RIA Novosti 2009).

Indeed, the speech given by Rakhmon to the PDPT party faithful in December 2009 was notable by the presence of several foreign delegations, including one from United Russia (Avesta, 2009). In fact, United Russia appears to enjoy regular contact and exchanges with its analogous partners in Kazakhstan, Tajikistan and Uzbekistan, well in line with notions of 'authoritarian linkage' mentioned by Levitsky and Way (2005) and others. Nur Otan, for example, was present at one of United Russia's earliest congresses in December 2004 as well as the party's post-election congress in May 2012, where the important subject of Eurasian integration was discussed (UR, 2012). In December 2011, a Nur Otan representative was invited to participate in a discussion at the influential United Russia think-tank, the Centre for Social Conservatism, where, among other things, more cooperation was called for between parties in neighbouring countries (CSCP, 2012). While cooperation between United Russia and Tajik and Uzbek parties of power has been less frequent, contact has none the less ensued; even more so if this contact is considered beyond the format of bilateral ties. For example, United Russia and the PDPT signed a cooperation agreement in Moscow in September 2011, while there is evidence of contact between Russian and Uzbek ruling parties as far back as 2004 (Bogomolov, 2004). But increasingly, United Russia is acting through international organisations to extend its contact with Central Asian parties. 
In March 2008, Konstantin Kosachev, the person responsible for managing United Russia's contacts with foreign political parties, announced that the party had successfully joined the International Conference of Asian Political Parties (ICAPP) - an organisation created in 2000 and including member parties from over 50 countries (UR, 2008). As of 2015, Andrei Klimov, represents United Russia in the organisation's standing committee, along with first deputy chair of Nur Otan, Bauyrzhan Baibek. The UzLidep and the PDPT are participating parties in this organisation.

The Inter-Parliamentary Assembly of the CIS, formed in March 1992, is yet another organisation that encourages cooperation between parties of power on a number of issues, including election observation. Based in St. Petersburg and currently under the chair of Russian Federation Council speaker, Valentina Matvienko, this organisation includes Kazakhstan and Tajikistan among its members (nine members, one observer), providing a forum for party leaders to pool their experience.

One may also include the aforementioned Russian Public Chamber as another organisation heavily influenced by United Russia which has a distinct international agenda. Even though the Public Chamber was created to regulate civil society in Russia, it has none the less elaborated a conception of its foreign activities. One priority area is the development of relations with civil society in other CIS states, notably the central Asian republics (OP, 2010). As already mentioned, the Public Chamber came into existence in 2007 but by May 2008, a memorandum on cooperation between Russian and Kazakhstani Public chambers was already in effect (Gazeta, 2008).

There also appears to be increasing linkage between parties of power and their youth wings. This linkage has a number of interfaces, notably the CIS 'Council on Youth Matters' (created in November 2005) and the 'Youth Council' of the Shanghai Cooperation Organisation (created in May 2009) which includes representatives from Russia, Kazakhstan, 
Uzbekistan and Tajikistan. The stated aim of the latter is to encourage cooperation and cultural exchanges between young leaders, through conferences and similar events. In August 2012, Armenia hosted the first 'Young Eurasia' forum, where youth groups from 15 CIS and Baltic states met to strengthen 'horizontal' ties between young politicians and, according to United Russia's youth organisation, to forward Vladimir Putin's vision of a Eurasian Union (MG, 2012b). This organisation also promotes the 'rebirth of eurasianism' (ME 2015) as the ideological component that underpins Eurasian integration and the newly formed Eurasian Economic Union, which came into existence in January 2015.

Levitsky and Way, suggest that party networks can be an effective way of affecting political outcomes $(2002,205)$ - although notions of party-based norm diffusion and, more generally, party-based 'soft power' are somewhat under-researched. In any case, United Russia was an organisation with a clear foreign policy objective from the outset. According to Valerii Bogomogov, United Russia's secretary of presidium of the general council, 2004-5, the party's early activities abroad were aimed at strengthening Russia's international authority and creating favourable conditions in other countries for Russia's economic and social development. Moreover, the five Central Asia republics were named as priority states, closely following the emphasis made by Putin in his early presidential addresses from 2002 onwards (Bogomolov, 2005).

\section{Building a hierarchic party system: a collaborative effort?}

So far, there is evidence of political convergence, at least in terms of similar parties of power and party systems in Russia, Kazakhstan, Tajikistan and Uzbekistan. There also appears to be linkage between parties of power and, in the case of Nur Otan and United Russia, substantial linkage. But, while there is a strong suggestion of successful Russian norm 
diffusion, the convergence on the hierarchic party system is a little more complex, the result of distinctly different processes in Russia and its Central Asian neighbours.

In essence, the political trajectories of Russia and the five Central Asian republics have been in opposite directions for much of the post-Soviet period. With the exception of Kyrgyzstan, and taking into account Kazakhstan's relative tolerance of dissent compared to Tajikistan, Turkmenistan and Uzbekistan (Piemani 2009, 126), the five former Soviet Central Asian republics began their post-Soviet existence by consolidating presidential power at the expense of democratic development, only later allowing a gradual increase in pluralism within their tightly controlled unitary states. Russia, in contrast, began independence with the pluralistic legacy of the late Soviet period. By the time of Putin's presidential election victory in 2000, this pluralism had led to the creation of hundreds of political movements, the emergence of a relatively free press and a variegated and loose form of federalism. As explained succinctly by the former senior official who worked for the Nazabaev Administration:

'Speaking of political issues, I mean the strong presidential vertical was built in Kazakhstan earlier than in Russia...after completing economic reforms, we started to let some of the elements of the vertical go autonomously. Things went the other way round in Russia - from unrestricted democracy to a strong presidential vertical'. (Personal Communication, October 28, 2007).

Further evidence can be seen in the development of parties of power in the states in question. In Kazakhstan, Tajikistan and Uzbekistan, 1991-2015, parties of power have been more enduring and more successful than their Russian counterparts. In short, presidential power, as a key requisite for establishing a dominant party of power and hierarchic party system, was consolidated later in Russia than in the central Asian cases in question.

In Kazakhstan, after an initial period of political liberalisation (Satpaev 2007, 284-5), the eventual consolidation of presidential power around Nursultan Nazarabev allowed for the 
formation of Otan, Nur Otan's predecessor, in February 1999. In Tajikistan, presidential consolidation around Ermilli Rahkmonov occurred later, although the PDPT was created as early as 1996. In the absence of either civil war or an early period of liberalisation, post-Soviet Uzbekistan saw presidential power consolidated by the mid-1990s and by the early 2000s, the Karimov regime had successfully developed a multi-party-of-power strategy.

Second, and perhaps the clearest indication that Central Asia states are not strictly following the Russian example is the fact that the conventions governing party systems in Kazakhstan, Tajikistan and Uzbekistan - namely the previously discussed party law markedly differ from the Russian variant. In Russia, the law 'On Parties' was signed into effect by president Putin in July 2001, signifying a key moment in the centralisation process and the formation of an all-national party of power. It is no coincidence that the steering committee for United Russia was actually formed on the same day that this law was signed (Ivanov, 2008, 78). The Russian law 'On Parties' is also extremely detailed, containing 48 articles relating to a host of party issues, including registration procedures and provisions to liquidate parties. In contrast, Tajikistan introduced a modest 16 article law on parties in November 1998, while in Kazakhstan (17 articles) and Uzbekistan (18 articles) this happened as early as 1996, although Kazakhstan subsequently introduced stricter party law in July 2002. The varying detail of these laws in no small way reflects the fact that by 2001 , Russia required a strong party law to reign in its hyper pluralistic party system, while the Central Asian regimes in question were using party law to stimulate party and party system development.

A more visible indication of this point can be seen in the fluctuation of the number of effective parliamentary parties in Kazakhstan, Tajikistan, Uzbekistan and Russia since 1991 (Figure 1). The number of effective parliamentary parties, as a measure, is based on the allocation of parliamentary seats, with a score of 1 indicating a legislature with just one party (constitutionally impossible in many states, but achieved in Kazakhstan following the 2007 
parliamentary election). This measure is highly misleading in the sense that it reflects party government-forming potential and hence party power, which in a context of controlled parties and controlled parliaments, is largely irrelevant for the cases in question.

But what this measure does show is the way that Russia mitigated the pluralism of the Yeltsin period with the 2001 law 'On Parties': the number of parties holding parliamentary seats, as well as the distribution of seats among them, sharply falling after 2001. In the other three cases in question, the establishment of party law in in the period 1996-8 shows the reverse trend of an initial increase in the number of effective parliamentary parties, indicating that party law was used to encourage party development rather than curtail it, as part of a process of partial regime liberalisation. In the case of Uzbekistan, the party system has seen a gradual increase in the number of loyal opposition parties from the first parliamentary elections held in 1993/4. As elections are not concurrent, Figure 1 groups parliamentary elections into six cycles. ${ }^{3}$

\footnotetext{
${ }^{3}$ These election cycles include six Russian, Kazakhstani, Uzbek and Tajik elections. Tajikistan's first postSoviet parliamentary election occurred in the second cycle in 1995, although the first multi-party election following the civil war was not until 2000.
} 
Figure 1 (Number of Effective Parliamentary Parties, 1993-2015)

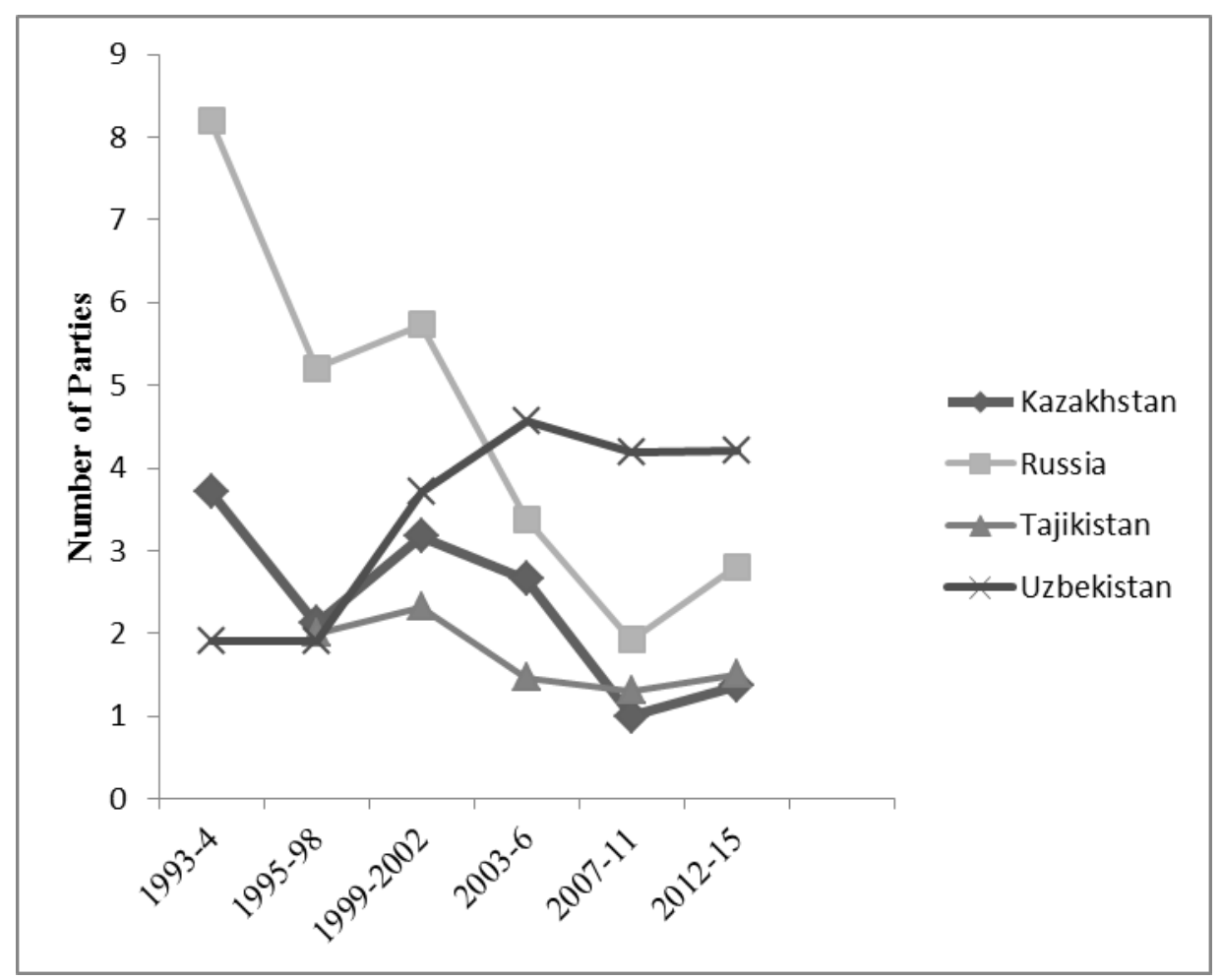

Source: election results taken from the Parline parliamentary data base (http://www.ipu.org/parlinee/parlinesearch.asp). The effective number of parties was calculated by the author using the Laakso and Taagepera formula (1979).

A third consideration relates to those prioritised ideas of 'unity' and 'sovereignty' that accompanied the development of the Russian hierarchic party system, with its dominant party of power and limited competition, packaged as a uniquely 'national' type of democracy. These ideas, it should be noted, were by no means new by the time Putin came to power in 2000 and by no means Russian. The ideas of 'unity' and 'sovereignty' are both tied to the final period of the Soviet Union, coming into stark relief with the civil war in Tajikistan, 1992-1997.

In addition, the idea of sovereignty as a rejection of a universal or 'Western democracy' in favour of a muted national form was evident among Central Asian leaders at around the same time they were consolidating their power. In Kazakhstan, Nazarabev's On the threshold of the twenty first century, published in 1996 gives a clear insight into his thoughts on political development, including his rejection of the 'global modernisation project' in 
favour of 'adaptive modernisation' $(1996,117)$ - understood to mean 'every state chooses its own model of democracy' (1996, 138). Nazarbaev also talks disparagingly of the 'shock of freedom' that, if unchecked, can lead to nationalism, populism, terrorism and constitutional crises $(1996,129)$.

Likewise, Karimov's similarly titled: Uzbekistan on the threshold of the twenty first century draws parallel conclusions, making a clear distinction between eastern and western traditions $(1997,177)$ while talking enthusiastically of the need to concentrate power in the executive branch to guide democratic development $(1997,153)$. The final part of Karimov's book emphasises the importance of 'non-interference in the internal affairs of other states' - a decade later the same idea was attributed to the Russian-Sino dominated Shanghai Cooperation Organisation as a norm designed to delegitimize anti-regime activities and democracy promotion (Ambrosio, 2008, 1341).

\section{Complex norm diffusion}

By 2015, part of the explanation for party system convergence in the region may be ascribed to norm diffusion, including Russian authoritarian norm diffusion. This includes the ability of the Russian regime to present a workable 'pseudo democratic' model to incumbents in other states and, undoubtedly, to share know-how directly with other parties of power, amenable to Moscow, within the post-Soviet space. But the path of post-Soviet regime development in the region, and by extension that of party system development, presents a more complex picture, suggesting two-way norm diffusion that includes processes of 'emulation' but also 'rejection', as incumbents seek solutions to similar political problems. ${ }^{4}$

Although less documented, it is clear that Russia not only diffuses norms in its near abroad, but also imports authoritarian practices too, which means that many aspects of post-

\footnotetext{
${ }^{4}$ See Omelicheva 2009 for a discussion of 'emulation' as an explanation for the convergence of counter terrorism polices in Central Asia.
} 
Soviet party system development, from the organisation of parties of power, to the norms of 'unity' and 'sovereignty', to methods for defrauding elections are likely to have a complex history and a number of surprising sources. Two clear examples help to underline this point.

First, the practice of voting 'ahead of schedule', which was widespread in Russia, July 2005-May 2010, and used to ease the logistical problems of voting in remote regions. This practice was widely criticised by opposition parties, who suspected the authorities of using early voting to commit electoral fraud and pad the vote for United Russia. But, this practice appears to have been imported from authoritarian Belarus, where the potential for fraud offered by the localised and low-profile nature of these elections was noted by observers as far back as the Belarusian presidential election of 2001 (ODIHR 2001: 21).

The second example concerns the thorny issue of presidential succession. While the Putin regime has so far resisted making far-reaching institutional changes to overcome the two-term presidential limit, in 2007, the State Duma approved amendments to the Constitution increasing presidential terms from four years to six years. However, this innovation is not as innovative as it seems. In January 2002, the Uzbek authorities held a referendum on extending presidential terms from five to seven years (Ilkhamov 2002: 8), in effect paving the way for, what many observers anticipate will be a 'president for life' status for Islam Karimov.

While these two examples only touch upon the wider subject of the normative origins of authoritarian regimes (including Russia's), the idea of complex norm diffusion involving emulation and rejection can be seen clearly in the two outlier Central Asian cases of Turkmenistan and Kyrgyzstan. In Turkmenistan, there are indications that the regime is about to follow the regional trend and establish a controlled party system in line with the hierarchic model already described. 
Until recently, Turkmenistan, was one of the world's few closed autocracies; the government controlling nearly every aspect of the economy (BTI 2012: 11$)^{5}$ in a de jure one party state, albeit dominated by the institution and personality of the president. The Democratic Party of Turkmenistan, as the party of power, was created in December 1991 and is the direct descendant of the Soviet era Turkmen Communist Party. However, in January 2012, Turkmenistan's first law 'On Parties' came into effect closely followed by the creation of a 'party of businessmen' overseen by the Union of Industrialists and Entrepreneurs in May 2012 (Khronika Turkmenistana 2012). The resulting Party of Industrialists and Entrepreneurs competed in the country's first ever multi-party elections in December 2013, gaining 14 seats in the 125 seat Mejlis (unicameral parliament). It has been reported that the main goal of this 'soft opposition' party is to support the government's efforts at strengthening the private sector (OSCE, 2013, 3).

Kyrgyzstan, on the other hand, appears to illustrate the difficulties of building a hierarchic party system, as well as the role of 'rejecting' political innovations seen elsewhere. In June 1999, the Kyrgyz Parliament (Zhorgorku Kensha) passed the republic's first law 'On Parties' in which the conditions for party registration and liquidation were outlined. However, on-going political instability and a hyper-fluid party system with almost 200 registered parties (MinJustKG 2015) means that Kyrgyzstan is considering changes, including new restrictions on party financing that could yet see the country's convergence on the same party system model seen elsewhere in the region.

However, there appears to be little prospect that a strict party law will gain traction in Kyrgyzstan in the current parliament's lifetime - one able to form the basis of a hierarchic party system. Interviews with representatives of parliamentary parties conducted in Bishkek in the spring of 2012 (Ata Metel, Ata Zhurt and Respublica) confirmed the attractiveness of the

\footnotetext{
${ }^{5}$ The Bertelsmann Stiftung's Transformation Index (BTI) evaluates democracy in 129 developing countries and provides in-depth country reports (http://www.bti-project.org/bti-home/)
} 
Russian party system model, as well as the influence of Russia over political processes in the country. But in the absence of consolidated presidential power in Kyrgyzstan, serious changes to the existing party law and party system are not envisaged. In what is perhaps a positive sign of democratic progress in the country (and confirmation of unconsolidated presidential power), the current parliamentary majority party (Ata Zhurt) is not the party of the president, although fresh parliamentary elections are due for October/November 2015.

Of greater significance is the acknowledgement that, although attractive, the hierarchic party system model, as seen in Russia, is neither perfect nor static. Representatives from each Kyrgyz party were quick to highlight the political instability that followed Russia's December 2011 parliamentary election - resulting, among other things, in amendments to Russia's existing party law in April 2012. ${ }^{6}$ There was also a degree of hostility toward the idea of incorporating yet more 'know how' from other states, as noted by a senior Ata Zhurk official: 'you know we've tried to use so many models here over the years that this place is starting to look like a laboratory’ (Personal Communication, May, 23 2012). In short, political elites in Kyrgyzstan, as across the post-Soviet space, continue to make calculations as to the effectiveness of political innovations seen in neighbouring regimes, ready to emulate and reject them, based on the dictates of their own unique circumstances.

\section{Conclusion}

Russia continues to develop and strengthen linkage with all former Soviet states in its 'near abroad', through cultural, economic and militarily channels, but also through political channels, such as the party of power, as this article has demonstrated. But in terms of explaining the curious party system convergence seen in Russia and post-Soviet Central Asia,

\footnotetext{
${ }^{6}$ Amendments to Russia's law 'On Parties' were made in March 2012, notably reducing membership requirements from 40,000 to 500. So far, these amendments have not altered the structure of the hierarchic party system, but have simply flooded the lower rung with soft opposition parties with little chance of passing the minimum threshold in regional or federal elections.
} 
there is clearly a complex process of norm diffusion at work, one that has seen the establishment of similar party system 'models' in Russia, Kazakhstan, Tajikistan and Uzbekistan, albeit from different start points.

Aside from the calculations of power-holders that encourage regimes to either emulate or reject political innovations seen elsewhere, it should be noted that, as of 2015 , there are at least two common problems faced by authoritarian regimes in the region that directly relate to party system development and that may predispose leaders to opt for similar solutions. The first is how to deal with the effects of economic pluralism, mostly from elites who seek opportunities to participate in political life in order to defend gains made through the process of privatisation. Allowing the formation of soft opposition parties may provide limited political influence to those who cannot find their place within the party of power. Economic pluralism also relates to the emerging middle class and how to absorb their demands for greater political participation. The second problem is an older one and is, in many ways, a remnant of the successful norm diffusion from the early 1990s. It concerns the issue of how to present an image of democracy to foreign and domestic audiences, while simultaneously maintaining power within an institutional framework that has at least some formal separation of powers. In any case, with serious questions surrounding economic growth, leadership succession and the very foundation of 'authoritarian stability' in the region, and with clear signs that some parties of power (notably, United Russia) are approaching the end of their lifespan, it remains to be seen how long party system convergence will persist. 


\section{List of references}

Ambrosio T., 2008. Catching the 'Shanghai spirit': how the Shanghai cooperation organisation promotes authoritarian norms in Central Asia. Europe-Asia Studies, 60 (8), 1321-1344.

Avesta, 2009 NDPT i KPT opredelyatsya so spiskami kandidatov dlya uchastiya v parlamentskikh vyborakh, http://www.avesta.tj/goverment/3376-ndpt-i-kpt-opredelyatsya-sospiskami-kandidatov.html (accessed 10.05.15).

Bacon, E., 2004. Russia's law on political parties: democracy by decree? In: Ross C (Ed.) Russian Politics under Putin. Manchester: Manchester University Press.

Bader M., 2009. Understanding Party Politics in the Former Soviet Union: Authoritarianism, Volatility, and Incentive Structures, Demokratizatsiya, 17 (2), 100-120.

Bader M., 2011. Hegemonic political parties in post-Soviet Eurasian: towards party based authoritarianism? Communist and Post-Communist Studies, 44, 189-197.

Bader J., Grävingholt., J and Kästner, A., 2010. Would autocracies promote autocracy? A political economy perspective on regime-type export in regional neighbourhoods.

Contemporary Politics, 16 (1), 81-100.

Bapakova, S. 2008. Kazakhstan-Rossiya: Memorandum o Vzaimoponimanii Obshchestvennykh Palat, http://www.zakon.kz/60509-podpisan-memorandum-o-vzaimoponimanii.html (accessed 10.05.15).

Bogomolov, V., 2004. Zarubezhnye partii-partnery 'Endinoi Rossii’ napravili prevetstviya uchastnikam v s"'ezda partii, http://www.allrus.info/main.php?ID=321501\&arc_new=1 (accessed 09.05.15).

Bogomolov, V., 2005. Ob Osnovnykh zadachakh i napravleniyakh razvitiya mezhdunarodnykh partiinykh svyazei partii ‘Endinaya Rossiya’ v 2004 godu, http://www.vbogomolov.ru/relationship/326.html (accessed 09.05.15). 
BTI, 2012. Turkmenistan Country Report, http://www.btiproject.de/uploads/tx_itao_download/BTI_2012_Turkmenistan.pdf (accessed 09.05.15).

Burnell, P., 2010. Is there a new autocracy promotion? Working paper 96, FRIDE, http://dialnet.unirioja.es/servlet/articulo?codigo=3188152 (accessed 10.05.15).

Cameron, D.R., and Orenstein, M., 2012. The influence of Russia in its 'near abroad'. PostSoviet Affairs, 28 (1), 1-44.

CSCP, 2012. Obshchestvennaya konsolidatsiya kak politicheskaya povestka dnya, http://www.cscp.ru/10000199/11426/? (accessed 10.05.15).

Del Sordi, A., 2011. Was the party of power exported from Russia to Kazakhstan? The diffusion of authoritarian institutions and values from Russia to Central Asia, paper prepared for the XXV Convegno SISP, Palermo, 8-10 September.

Duverger, M,. 1964. Political Parties: Their Organisation and Activities in the Modern State. London: Methuen.

Freedom House, 2012a Kozlov conviction in Kazakhstan a miscarriage of justice, https://freedomhouse.org/article/kozlov-conviction-kazakhstan-miscarriagejustice\#.VU4hxpVFB9A (accessed 10.05.15).

Freedom House, 2012b. Increasing Pressure on Opposition Party in Tajikistan Raises Concerns of Crackdown, https://freedomhouse.org/article/increasing-pressure-opposition-partytajikistan-raises-concerns-crackdown\#.VVH6G5VFB9A (accessed 11.05.15).

Finnemore, M., and Sikkink, K., 1998. International norm dynamics and political change. International Organisation, 52 (4), 887-917.

Gazetta, 2008. Obshchestvennye palaty Kazakhstana i Rossii podpicali memorandum o vzaimoponimanii, http://news.gazeta.kz/art.asp?aid=231639 (accessed 10.05.15).

Heathershaw, J., 2009. Tajikistan's Virtual Politics of Peace. Europe-Asia Studies, 61 (7), 13151336. 
Hutcheson, D., 2012. Party Cartels: Beyond Western Europe. Party Politics, 1-18.

Hyde, S., 2011. Catch us if you can: election monitoring and international norm diffusion, American Journal of Political Science, 55 (2), 356-369.

Ivanov, V., 2008. Partiya Putina: Istoriya Edinoi Rossii. Moscow: Ulma.

Ishiyama, J., 2008. Political Party Development and Party 'Gravity' in Semi-Authoritarian States: The Cases of Azerbaijan, Kyrgyzstan, and Tajikistan, Taiwan Journal of Democracy, $4(1), 33-53$.

Karimov, I., 1997. Uzbekistan na poroge XXI veka: Ugroziy bezopasnosti, Uslovie I garantii progressa. Uzbekiston: Tashkent.

Kästner, A., 2010. Russia: supporting undemocratic tendencies in the post-Soviet space? Briefing Paper 2/2010, German Development Institute, http://www.diegdi.de/uploads/media/BP_2.2010.pdf (accessed 10.05.15).

Karvonen, L., 2007. Legislation on political parties: global comparison, Party Politics, 13, 437455.

Khronika Turkmenistana, 2012. V Turkmenistane nachalos' sozdanie politicheskoi partiii, http://www.chrono-tm.org/2012/05/v-turkmenistane-nachalos-sozdanie-politicheskoy-partii/ (accessed 10.05.15).

Kramer, M., 2008. Russian policy toward the Commonwealth of Independent States: recent trends and future prospects, Problems of Post-Communism, 55 (6), 3-19.

Laakso M., and Taagepera R,. 1979. Effective Number of Parties: A Measure with Application to West Europe, Comparative Political Studies, 12 (1), 3-27.

Levitsky S., and Way, L., 2005. International Linkage and Democratization, Journal of Democracy, 16 (3), 20-34.

Levitsky, S., and Way, L., 2010. Competitive Authoritarianism: Hybrid Regimes after the Cold War. New York: Cambridge University Press. 
Lillis, J., 2012. Kazakhstan: Court shuts key opposition party, EurasiaNet, http://www.eurasianet.org/node/66330 (accessed 07.05.2015).

Manners, I., 2002. Normative Power Europe: A Contradiction in Terms? Journal of Common Market Studies, 40 (2), 235-58.

ME, (2015) O dvizhenii, http://yeurasia.org/movement/ (accessed 13.05.2015)

Mills, A., and Joyce, D., 2006. Non-governmental organisations in international norm transmission on the fault lines of the international order, Cambridge Review of International Affairs, 19 (1), 11-19.

MinJust, 2015. Vserossiiskoi politicheskoi partii 'Edinaya Rossiya', http://minjust.ru/ru/vserossiyskaya-politicheskaya-partiya-edinaya-rossiya-6 (accessed 10.05.15).

MinJust KG, 2015. Spikok politicheskii Partii, http://minjust.gov.kg/?page_id=6551 (accessed 10.05.2015).

MG, (2012) Ustav, http://mger2020.ru/content/2012/05/23/34022 (accessed 10.05.15).

MG, (2012) Molodaya Gvardiya obsudila bydyshchee Evraziickovo Soyuza na Forume ‘Molodaya Evraziya' v Armenii. http://mger2020.ru/nextday/2012/08/26/37816 (accessed 10.05.15)

Moraski, B., 2006. Mandating party development in the Russian federation: effects the 2001 party law. Journal of Elections, Public opinion \& Parties, 16 (3), 199-219.

Moiseev, D., 2007. Chelyabinskie edinorossy stavyat na zhenskii bokc, http://www.ng.ru/ regions/2007 -08-29/5_box.html (accessed 10.05.15).

Nazarbaev, N., 1996. Na poroge XXI veka. Oner: Almaty.

Nikitina, M., 2008. Budem Podderzhivat'. Vremya, http://www.time.kz/index.php?module= news\&newsid=4699 (accessed 11.05.15). 
Novak, A., 2012. Vladimir Ryzhkov dobilsya svoevo Minust zaregistiroval RPR-PARNAS, Kommersant', http://www.kommersant.ru/doc/1993651 (accessed 10.05.15).

Novaya gazeta, 2015. Sud priznal zakonnym zapret 'Partiya progressa' na uchastie v vyborakh, http://www.novayagazeta.ru/news/1691184.html (accessed 10.05.15)

Nur Otan, 2007. Programma narodo-demokraticheskoi partii ‘Nur Otan', http://www.ndpnurotan.kz/site/content/17 (accessed 10.10.12).

Nur Otan, 2013. Ustav, http://nurotan.kz/ru/ustav (accessed 14.05.15).

OP, 2010. Kontseptsiya Mezhdunarodnoi deyatel'nosti Obshchestvennoi Palaty Rossiiskoi Federatsii, http://www.oprf.ru/ru/documents/498/1844/newsitem/18262 (accessed 10.05.15).

ODIHR, 2001. Republic of Belarus Presidential Election 9 September 2001, OSCE/ODIHR Election Observation Mission Report, http://www.osce.org/odihr/elections/belarus/14459 (accessed 10.05.15).

Okara, A., 2007. Sovereign Democracy: A New Russian Idea or a PR Project? Russian in Global Affairs, 5 (3), 8-20.

Omelicheva, M., 2009. Convergence of counterterrorism policies: a Case study of Kyrgyzstan and Central Asia. Studies in Conflict \& Terrorism, 32, 893-908.

OSCE, 2007. Limited Election Observation Mission Republic of Uzbekistan Presidential Election 2007, http://www.osce.org/odihr/elections/uzbekistan/29880 (accessed 10.05.15).

OSCE, 2013. Turkmenistan: Parliamentary elections 15 December 2013, http://www.osce.org/odihr/elections/116011?download=true (accessed 10.05.15).

OSCE, 2015(a). Limited Election Observation Mission Republic of Uzbekistan Presidential Election 2015, http://www.osce.org/odihr/elections/tajikistan/143306?download=true (accessed 09.05.15). 
OSCE, 2015(b). Limited Election Observation Mission Republic of Uzbekistan Presidential Election 2015, http://www.osce.org/odihr/elections/uzbekistan/148186?download=true (accessed 09.05.15).

PDPT, 2015. Ustav, http://www.tribun.tj/ru/statute (accessed 14.05.15).

Peimani, H., 2009. Conflict and Security in Central Asia and the Caucasus. ABC-CLIO: Santa Barbara.

Peleschuk, D., 2012. Voting for Legitimacy. Russia Profile, http://russiaprofile.org/international/52837/print_edition/ (accessed 10.05.15).

Pevehouse, J., 2002. Democracy from the outside-in? International organizations and democratization. International Organisation 56 (3), 515-49.

UR, 2008. MKAPP dlya 'Edinoi Rossii - Perspektivnyi i Konstruktivnyi Partnep, http://www.qwas.ru/russia/edinros/id_97683/(accessed 10.05.15).

UR, 2012. Evraziskiiskii proekt pozvolit chelovechestvu prodvinut'sya vpered, http://voronezh.er.ru/news/2012/5/26/evrazijskij-proekt-pozvolit-chelovechestvuprodvinutsya-vpered/(accessed 10.05.15).

UR, 2013. Ustav, http://er.ru/party/rules/ / (accessed 10.05.15).

UR, 2015. Partiya 'Edinaya Rossiya' segodnya http://er.ru/party/today/ (accessed 10.05.2015).

Radiotochka (2015) O partii 'Nur Otan'fakty i tsifry infografika, http://radiotochka.kz/8701-opartii-nr-otan-fakty-i-cifry.html (accessed 12.05.15).

RIA Novosti, 2009. Prezident Takzhikistana vnov’ izbran glavoi pravyashchei NDPT http://ria.ru/politics/20091227/201678271.html?ria=t2o8jouimdo6nqlv34rrtcgtkh04frdv (accessed 14.05.15)

Roberts, S., 2012a. United Russia and the dominant-party framework: Understanding the Russian party of power in comparative perspective, East European Politics, 28 (3), 225-240. Roberts, S., 2012b Putin's United Russia Party. Routledge: Oxon. 
RG, 2007. Ukaz 1274: Voprosy Struktury Federal'nykh Organov Ispolnitel'noi Vlasti, http://www.rg.ru/2007/09/26/struktura-dok.html (accessed 10.15.15).

Salikh, M., 2013 Uzbekistan: Oppozitsioner Mukhammad Salikh nastaivaet na tom, chto infarkt u prezidenta Karimova vse zhe byl http://www.fergananews.com/news/20395 (accessed 14.05.15)

Satpaev, D. 2007. An Analysis of the Internal Structure of Kazakhstan's Political Elite and an Assessment of Political Risk Levels. In Uyama T (Ed.) Empire, Islam, and Politics in Central Eurasia. Sapporo: Slavic Research Center, pp. 283-300.

Schedler, A., 2006 The Logic of Electoral Authoritarianism. In: Schedler A (Ed.) Electoral Authoritarianism. London: Lynne Rienner, pp. 1-23.

Smyth, R., Lowry, A., and Wilkening. B., 2007. Engineering Victory: Institutional Reform, Informal Institutions and the Formation of a Hegemonic Party Regime in the Russian Federation. Post-Soviet Affairs 23 (2) 118-37.

Tolstrup, J., 2009. Studying a negative external actor: Russia's management stability and instability in the 'near abroad'. Democratization 16 (5), 922-944.

Tret'yakov, V., 2007. Suverennaya Demokratiya. In: Pavlovskii G (Ed.) Pro Suverennuуu Demokratiyu. Moscow: Evropa, p. 627.

UzLidep, 2014. Predvybornaya programma dvizheniya predprinimatelei i delovikh lyudei liberal'no-demokraticheskoi partii uzbekistana, http://www.uzlidep.uz/ru/about/predvybornaya-programma (accessed 14.05.15).

UzLidep, 2015. Ustav, http://www.uzlidep.uz/ru/about/ustav-partii (accessed 14.05.15).

Zakon.kz (2008) V Kyzylordinskom oblastom filiale NDP ‘Nur Otan’ proveden vnutripartiinyi praimeriz, http://www.zakon.kz/117396-v-kyzylordinskom-oblastnom-filiale-ndp.html (accessed 14.05.15) 
ZO, 2015. Ustav, http://vk.com/doc-42366241_134136444?dl=28aabb49a7217e1962 (accessed 10.05.15). 